\title{
A half-baked solution: drivers of water crises in Mexico
}

\author{
Jonatan Godinez Madrigal $^{1,2}$, Pieter van der Zaag $^{1,2}$, and Nora van Cauwenbergh ${ }^{1}$ \\ ${ }^{1}$ Department of Integrated Water Systems and Governance, IHE-Delft, Delft, 2601 DA, the Netherlands \\ ${ }^{2}$ Department of Water Management, TU Delft, Delft, 2628 CN, the Netherlands
}

Correspondence: Jonatan Godinez Madrigal (j.godinezmadrigal@un-ihe.org)

Received: 7 June 2017 - Accepted: 4 August 2017 - Published: 1 February 2018

\begin{abstract}
Mexico is considered a regional economic and political powerhouse because of the size of its economy, and a large population in constant growth. However, this same growth accompanied by management and governance failures are causing several water crises across the country. The paper aims at identifying and analyzing the drivers of water crises. Water authorities seem to focus solely on large infrastructural schemes to counter the looming water crises, but fail to structure a set of policies for the improvement of management and governance institutions. The paper concludes with the implications of a business-as-usual policy based on infrastructure for solving water problems, which include a non-compliance to the human right to water and sanitation, ecosystem collapses and water conflicts.
\end{abstract}

\section{Introduction}

Mexico is a rich and diverse country with a multitude of ecosystems, ranging from water-rich jungles to dry deserts. The country's economy is among the top ten in the world, and second in Latin America. Socio-economic dynamics and water distribution are interlinked, and vary across the country, with a mainly agricultural south, with as much as $11768 \mathrm{~m}^{3} \mathrm{cap}^{-1} \mathrm{yr}^{-1}$ of water availability, producing $20 \%$ of the GDP and with a $23 \%$ of the population, and a heavily industrialized center and north with a low water availability of $1650 \mathrm{~m}^{3} \mathrm{cap}^{-1} \mathrm{yr}^{-1}$ and $80 \%$ of GDP and $77 \%$ of the population (Conagua-Semarnat, 2016). Regardless of the south having high water availability, still close to $20 \%$ of the population lack water supply and sanitation, while the semi-arid north almost achieves $100 \%$ coverage (Gobierno de Mexico, 2014). After a 2014 reform to the constitution granting the human right to water and sanitation, the State must guarantee water supply and sanitation to all the population through the local government. To comply with this human right is a daunting task without putting more pressure to water resources, as the current population surpasses 119 million people (INEGI, 2015), which by 2050 is expected to grow to 150 million (Conapo, 2017b). Another pressure on water resources comes with another commitment from the State, which is to reduce poverty, as currently 55 million
Mexicans are being considered poor (Coneval, 2017). Recently, the Mexican Government has focused on structural reforms to improve economic growth - along with its concomitant water use, as the only way to put people out of poverty (Gobierno de Mexico, 2017).

These socio-economic tendencies along with the geographical distribution of water has severely strained the water resources in general, and unevenly affected the population. Mexico is approaching several water crises that are recognized by some government institutions, by civil society and scholars (COMDA et al., 2017; Conagua-Semarnat, 2014; Peña-Ramirez, 2012). The most serious four are (1) the growing gap between a sustainable supply and the unrelenting demand, (2) the growing pollution of aquatic ecosystems, (3) urban/rural water access crises and (4) vulnerability under climate change, as described in more detail in Table 1. In order to face these challenges, Conagua (National Water Commission) has embarked on the development of large infrastructural projects like dams, interbasin water transfers and water treatment plants under public-private partnerships. However, following Madani (2014) on the underlying causes of water crisis, water agencies tend to focus only on a "symptom-based management paradigm", rather than addressing the drivers of water crises, defined as the root of the water problems characterized by its dynamism and pervasiveness embedded in the social system. Conagua 
is the central authority that administers water in Mexico including infrastructure development, quality and quantity water monitoring, water distribution, and issuing of water rights. There are also river basin councils across the country, but Conagua's weight in decision-making still is overwhelming.

The main purpose of this paper is to analyze the water crises in Mexico and its concomitant drivers. The paper is based on an extensive literature review on the dynamics of water problems Mexico has faced over the past decade. First, official data and documents from Conagua and other government agencies related to water were analyzed to picture a narrative paired with data. Second, an analysis was undertaken on critical scientific articles and books that analyze indepth the socio-political context to the water problems first described. This exercise was subsequently enriched and extended with field work during the first half of 2017 when interviews with water agencies officials and stakeholders were held. The outcome of the analysis of these three sets of data and narratives is the synthesis presented in Table 1.

The structure of the article is as follows: the corpus of the paper analyses each of the four water crises mentioned and their drivers, and then the socio-environmental implications that these crises may carry are discussed, then the paper ends with the concluding remarks.

\subsection{Growing gap between water supply and demand}

The current gap in the national water balance mounts to $11500 \mathrm{hm}^{3} \mathrm{yr}^{-1}$, as the sustainable water supply (water use that does not compromise ecological flows nor comes from overexploited aquifers) is estimated to be $66900 \mathrm{hm}^{3} \mathrm{yr}^{-1}$ and the water use of all water users is estimated to be $78400 \mathrm{hm}^{3} \mathrm{yr}^{-1}$ (36\% of it being underground water); this gap is only destined to widened in the future, with an expected doubling to $23000 \mathrm{hm}^{3} \mathrm{yr}^{-1}$ (Conagua-Semarnat, 2014). All uses are expected to grow: agriculture, public and industrial. Currently, Mexico has 6 rivers among the world's most depleted freshwater sources, causing high competition between users and depletion of ecological flow (Richter, 2014), the number 7 in the world for most water extracted (Conagua-Semarnat, 2016), and is among the top countries of groundwater consumption that exceeds its recharge (World Economic Forum, 2011), Mexico being the largest groundwater user in Latin America (Scott and Banister, 2008), with $23 \%$ of its aquifers presenting over-exploitation or saline intrusion (Conagua-Semarnat, 2016). The general trend is that water availability per capita will decrease in time as population increases. Water availability in Mexico will drop from more than $5000 \mathrm{~m}^{3} \mathrm{cap}^{-1}$ in 1990 , to less than $3,000 \mathrm{~m}^{3} \mathrm{cap}^{-1}$ by 2050 , whilst Mexico City currently only has a per capita annual water availability of $150 \mathrm{~m}^{3}$.

Economic growth is promoted regardless of water availability in the region. Decision-making on water allocation rights is still dominated by big players in river basin councils as underground water rights are granted to large food and mining corporations in water scarce regions (COMDA, 2017; Stoltenborg and Boelens, 2016), who use their economic influence to get additional water rights despite drilling bans in place by Conagua, as found during fieldwork in early 2017 . Reis (2014) documented how the water authority allowed the existence of the black market in the Valley of Mexico basin, where powerful stakeholders could buy out thousands of cubic meters from impoverished farmers. Although the drilling bans is set in order to recharge over-exploited aquifers, the black market inhibits the sustainable use of them.

Public participation in river basin councils still has no influence on decision-making due to co-opted participation of its sectors' representatives, which represent political interests rather than their constituents' (Mollard et al, 2010). This tilts the debate towards a focus on pre-existing economic interests, and jeopardizes the sustainability of water management. Some attempts have been made to integrate a self-regulation institution aimed at metering underground water extraction and enforcing water use according to water rights to tackle aquifer over-exploitation in closed basins, but it has failed due to political struggles and low user participation (Wester et al., 2009).

Agriculture, the largest water consumer in Mexico, has a great potential to free-up water that can be re-allocated, as at least $14 \%$ of the water allocated to irrigation are water losses that can be avoided. By far the largest part of these avoidable losses occur in the semi-arid north, where a considerable amount of that water evaporates, and thus are considered consumptive losses; avoiding these would really imply net water savings. Despite this situation, the budget to modernize agriculture is smaller than the construction of a single water supply dam (Gobierno de Mexico, 2014).

\subsection{Pollution of aquatic ecosystems}

Although each year new water treatment plants are built in the country, still almost $70 \%$ of all industrial and $50 \%$ of municipal wastewater and its raw sewage goes untreated into surface bodies of water and the sea (Conagua, 2015). With such numbers it can be assumed that water quality has deteriorated over time; however water quality monitoring has been compromised due to a change in the norms and standards by Conagua in 2002. Therefore there are substantial differences in how water quality performance is recorded, which makes it difficult to assess whether water quality of most water bodies in Mexico has improved or deteriorated over time (Aboites et al., 2008; Hansen and Juárez-Corzo, 2011). This notwithstanding, it is estimated that $20 \%$ of aquifers and over $30 \%$ of surface water are polluted (Conagua-Semarnat, 2016). Currently, there are only three official parameters for monitoring pollution: chemical oxygen demand, biological oxygen demand and total suspended solids. Despite signing the Stockholm convention on Toxic, Persistent and Bioaccumulable Substances (TPBS), Conagua has not monitored TPBS in river basins (Hansen and Juárez-Corzo, 2011). 
Table 1. Drivers of water crises in Mexico.

\begin{tabular}{|c|c|c|c|c|}
\hline & $\begin{array}{l}\text { Growing gap between sustainable } \\
\text { water supply and demand }\end{array}$ & Pollution of aquatic ecosystems & Urban/rural water crisis & $\begin{array}{l}\text { Vulnerability under stochastic meteorological } \\
\text { events - droughts and floods }\end{array}$ \\
\hline \multirow[t]{3}{*}{ Drivers } & Population and economic growth & Outdated pollutants regulations & $\begin{array}{l}\text { Underfunded water utilities, prone } \\
\text { to pork-barrel politics }\end{array}$ & $\begin{array}{l}\text { Flawed metering, monitoring and } \\
\text { legal enforcement of water use }\end{array}$ \\
\hline & $\begin{array}{l}\text { Inefficient agriculture } \\
\text { and operation of built infrastructure }\end{array}$ & $\begin{array}{l}\text { Lack of infrastructure and deficient maintenance } \\
\text { to leakages and bad water quality }\end{array}$ & Old distribution system, prone & Chaotic urbanization \\
\hline & $\begin{array}{l}\text { Flawed monitoring metering, } \\
\text { and law enforcement }\end{array}$ & $\begin{array}{l}\text { Lack of monitoring and law enforcement - } \\
\text { self-regulated industries }\end{array}$ & $\begin{array}{l}\text { Unsustainable and/or conflictive } \\
\text { water sources }\end{array}$ & $\begin{array}{l}\text { Over-reliance in large infrastructure } \\
\text { for water supply }\end{array}$ \\
\hline
\end{tabular}

According to Mexican Law, local governments oversee operation and management of water treatment plants, but operation costs are high, and financial and technical capacity to cover those costs is mostly absent. This situation causes water treatment plants to deteriorate and many fall rapidly into obsolescence (Ramón-Lahera, 2010). This explains why out of a total of $210 \mathrm{~m}^{3} \mathrm{~s}^{-1}$ of waste water produced in the country, only $99.8 \mathrm{~m}^{3} \mathrm{~s}^{-1}$ are treated, despite installed infrastructure with the potential for $140.1 \mathrm{~m}^{3} \mathrm{~s}^{-1}$ if adequately maintained (Gobierno de Mexico, 2014). Even though this model of water treatment is obviously flawed, the main funding for new water treatment plants is allocated exclusively for capital intensive water treatment plants, instead of more passive treatment plants like constructed wetlands or hybrid systems that do not require an overwhelming technical and financial capacity for rural areas or small cities.

The urban model prevalent in Mexican cities makes water treatment complex, as industrial and residential zones are often mixed, thwarting the function of the water treatment plants that are designed either for municipal or industrial wastewater (Ramón-Lahera, 2010). Therefore, most wastewater considered as having been treated does not comply with the standards of receiving water bodies.

Monitoring point source pollution has become a daunting task as resources allocated are far from sufficient. For example, only as few as 214 inspectors are in charge of monitoring close to 475000 water users that discharge polluted water. With this level of inspection it would take 61 years to check all water users (McCulligh, 2017). To solve this problem, there is a self-regulation policy, without any guarantee of industries reporting real data, and in the case of proven misconduct, industries can easily evade a fine by issuing a complaint on the procedure, which Conagua often accepts, dropping the charges (Ibíd.). Water quality is increasingly becoming an issue dominated by conflict, as most Mexican rivers are polluted, especially by unregulated industries. This situation has evolved into an issue of public health, as many riparian communities near heavily polluted rivers present a surge of skin diseases, kidney failure, and many kinds of cancer (Lezama, 2016).

\subsection{Urban/rural water crisis}

According to official data, Mexico has achieved a water supply coverage of $92 \%$ of the population. However, this data should be questioned, as it mainly counts infrastructure, not real access to a continuous flow of good quality water, as suggested by COMDA et al. (2017). Water scarcity in major cities is becoming a usual phenomenon (Peña-Ramirez, 2012). Some peri-urban areas in major cities get their water supply through water tank pipes, despite having water connection to a centralized water storage system, as the faucet is dry due to water rationing (Gómez-Valdez and PalermViqueira, 2015). Such situation affects mainly the poorest at the bottom quintile (COMDA et al., 2017). Poor water access can be so critical that it can become a flagship promise for some politicians to get elected. Conditional water supply in exchange for votes has been a documented issue for a number of decades, especially in Mexico city (Castro, 2006; Quintero, 2004). This pork-barrel politics goes contrary to an ideal public participation in the management of water supply and sanitation services (WSS), which could explain the delay in the universal cover of WSS (Torregrosa-Armentia and Jimenez-Cisneros, 2009). Additionally, water utilities across the country have a high level of non-revenue water-ranging from 30 to even $50 \%$ (SEMARNAT, 2009) and low price per cubic meter, which inhibits cost recovery for the water utilities that cannot invest in construction of new infrastructure and maintenance of the distribution network, an argument often used for warranting privatization, despite international evidence on the contrary (Schouten and Schwartz, 2006). Water prices remain politically contentious as politicians do not want to implement unpopular policies, such as an increment in the price of water, therefore water utilities remain helplessly dependent on subsidies to keep operating. In the year 2017 a cutback was announced of around $70 \%$ to these subsidies, a situation that water advisors to the federal congress deem as potentially critical for water utilities across the country (García, 2016), which may start dropping the already subpar quality of WSS. Water utilities cannot guarantee the quality of tap water for human consumption in many cities of the country, triggering one of the most profitable bottled water markets in the world (Pacheco-Vega, 2015), with grim consequences for those 55 million poor, who spend a high percentage of their income on water, ranging from 5 to $15 \%$ (Greene, 2017).

Aquifers are the main water source for large cities, providing up to $70 \%$ of total water supply. This has led to a serious problem of land subsidence. Mexico City, for example, draws water from approximately 600 wells $\left(59 \mathrm{~m}^{3} \mathrm{~s}^{-1}\right)$, and land 
level is dropping at a rate of 12 to $22 \mathrm{~cm} \mathrm{yr}^{-1}$ (Kimmelman, 2017). Mexico City only has $150 \mathrm{~m}^{3}$ per capita per year of water availability, already counting several interbasin water transfer schemes. The Cutzamala scheme, one of the largest interbasin transfers in the world and usually praised for its engineering, is also the reason for an on-going water conflict with local indigenous people in the donor basin with severe water scarcity due to the water transfer (Gómez-Fuentes, 2014; Watts, 2015). Despite water conflicts, Conagua is already looking for new sources of water for another water transfer, as Mexico City is still running on deficit.

The tendency of Mexican cities is to keep growing while the countryside stagnates or even loses its population due to migration to cities. At the same time, rural needs have remained a point of contention for the lack of investment in infrastructure, which the urban areas quadruples that of rural areas (Conagua-Semarnat, 2015). This disparity in terms of investment in water infrastructure and other services, in which 3 out of 4 localities are considered marginalized (Conapo, 2017a), has led to an intense migration from rural to urban areas of people looking for a better living standards and opportunities.

\subsection{Vulnerability under stochastic meteorological events - droughts and floods}

In a climate change scenario provided by IPCC a reduction of $15.2 \%$ rain is expected by 2030 and an increased pressure on water resources in the northern part of the country, while in the south more precipitation is expected and more floods (Martínez-Austria and Patiño-Gómez, 2012).

Mexico is prone to droughts, the most recent one of 20112012 being the worst in 70 years, with an agricultural economic loss of USD 1.3 billion, and an overall loss of $10 \%$ of the GDP (Ortega-Gaucin et al., 2016). The country has shifted from a crisis management approach to a risk management one (Korenfeld-Felderman et al., 2014), through the National Drought Program (PRONACOSE for its Spanish acronym). The program is intended to lay out a set of preventive and mitigation actions to enhance the socio-ecological resilience should droughts strike. However, the measures planned to undertake in cases of drought, although a general improvement from the previous approach, whose sole measure was the access to a disaster fund and some relief measures, still is largely based on the status quo that elicits the other drivers of water crises.

Mexico City, Guadalajara, Monterrey and Leon, the largest cities in Mexico, present a recurrent problem on floods and water scarcity (Delgado-Ramos, 2015; Peña-Ramirez, 2012). These cities have undertaken simultaneously expensive infrastructural works at controlling urban floods and interbasin water transfers (Gobierno de Mexico, 2014). This situation can be explained by chaotic urbanization and land use, land speculation, and the loss of natural capital. However, instead of tackling these underlying causes, these cities persistently aim at solving these recurrent problems by developing large infrastructure and moving the water transfer frontier continuously further. This solution lacks flexibility and resilience to extreme meteorological events (Delgado-Ramos, 2015), and leaves the cities vulnerable to extremes such as droughts and floods, which especially affects the poor in peri-urban areas (von Bertrab and Wester, 2005).

\section{Discussion}

The combination of the four water crises described have at least three implications: the non-compliance with the human right on water and sanitation, ecosystems collapse and water conflicts. As the water stock is finite and diminishing faster than it is being replenished, and the population and the economy keeps growing, the gap between water supply and demand will continue to widen further. As cities most likely will keep accommodating the population and economic growth, they will be more dependent on water transfers and other large infrastructures to keep up with the demand for WSS, but always lagging behind the real demand. With scarce financial resources, water utilities in urban and rural settings will never reach a $100 \%$ coverage in WSS, a situation that is advantageous for political careerism who address the water deficit partially and temporally in times of elections. Competition for water resources will become ever more acute as the agriculture, the largest water user, does not have the resources to modernize its infrastructure to diminish its wasteful use of water, and the higher returns for industry and public use shall translate in more pressure to reallocate water. Therefore, combined with a flawed water treatment system, the biggest loser will be the ecosystems and people dependent on them. Finally, the chaotic urbanization and the rising pressure in water resources and extreme meteorological events may increase the vulnerability of urban residents to floods and droughts, causing even more water conflicts.

\section{Conclusions}

This study shows that there are two kinds of drivers of water crises in Mexico: population and economic growth and water management and governance failures. Serious consideration and investment is only put into the first kind of water drivers through supply augmentation through large infrastructural schemes like dams, water transfers and water treatment plants. Although they may be deemed necessary for WWS, they also need to be complemented by institutional improvements that can anticipate and address water crises at a more fundamental level. Some policies that can improve this second kind of driver include the following:

- water utilities' independence from local and regional politics and funding, 
- public participation in decision-making processes for water distribution agreements, in the design and scale of infrastructure, and in setting compensations for affected populations,

- transparency in contracts,

- access to reliable hydrological information,

- tackling pervasive corruption in allocation of water rights,

- updated regulation and norms of water pollution,

- law enforcement of water use and water pollution.

Although these polices are standard, the question lies in how to effectively implement them. The Lerma-Chapala case study in Mexico, is considered a success story regarding the management of a water crisis of a closed basin (Hidalgo and Pena, 2009). However, the IWRM approach used there have not yet been applied to other basins facing other kind of crises. As noted in Lenton and Muller (2009) international experiences teach that better water management is usually dependent on political processes outside the water sector. Political feasibility is key to policy changes based on different water management paradigms (Allen, 2003). Mexico is currently in the arduous political process of implementing a new fully coherent water policy based in tackling the drivers of water crises described.

Data availability. Data are available upon request by the corresponding author.

Competing interests. The authors declare that they have no conflict of interest.

Special issue statement. This article is part of the special issue "Water security and the food-water-energy nexus: drivers, responses and feedbacks at local to global scales". It is a result of the IAHS Scientific Assembly 2017, Port Elizabeth, South Africa, 10-14 July 2017.

Acknowledgements. I want to thank Heliodoro Ochoa-García for his commendable feedback and comments on this paper.

Edited by: Barry Croke

Reviewed by: two anonymous referees

\section{References}

Aboites, L., Cifuentes, E., Jimenez, B., and Torregrosa, L.: Agenda del agua, Mexico city: Academia Mexicana de Ciencias, 2008.

Allan, J. A.: IWRM/IWRAM: a new sanctioned discourse? School of Oriental and African Studies, Occasional, 1-27, 2003.

Castro, J. E.: Water, Power and Citizenship Social Struggle in the Basin of Mexico, New York: Palgrave Macmillan, 2006.

COMDA, MAPDER, AMCF, TODXS, A. P., DESC, E., RGEMA, MUPCND: Informe sobre violaciones a los Derechos Humanos al Agua y Saneamiento en México, 2017.

Conagua-Semarnat: Plan Nacional Hídrico 2013-2018, 2014.

Conagua-Semarnat: Situación del subsector agua potable, alcantarillado y saneamiento a diciembre de 2015, 2015.

Conagua-Semarnat: Estadísticas del Agua en México 2016, available at: www.gob.mx/conagua (last access: 7 September 2017), 2016.

Conapo: Localidades rurales, available at: http://www.conapo.gob. mx/es/CONAPO/Localidades_rurales (last access: 4 June 2017), 2017a.

Conapo: Proyecciones de población, available at: http://www. conapo.gob.mx/es/CONAPO/Proyecciones_Datos\%0D, (last access: 25 May 2017), 2017b.

Coneval: Pobreza en México, available at: http://www.coneval.org. $\mathrm{mx} /$ Medicion/Paginas/PobrezaInicio.aspx, last access: 30 May 2017.

Delgado-Ramos, G. C.: Water and the political ecology of urban metabolism: the case of Mexico City, Journal of Political Ecology, 22, 98-114, 2015.

García, I.: Crisis líquida, Reporte Índigo, available at: http: //www.reporteindigo.com/reporte/mexico/pef-escazes-agua (last access: 7 September 2017), 2016.

Gobierno de Mexico: Programa Nacional de Infraestructura 2014-2018, available at: http://www.dof.gob.mx (last access: 7 September 2017), 2014.

Gobierno de Mexico: Reformas estructurales y expectativas de crecimiento de la economía y de la productividad, available at: https://www.gob.mx/cms/uploads/attachment/file/160126/II_ Reformas_Estructurales-1.pdf (last access: 7 September 2017), 2017.

Gómez-Fuentes, A. C.: Estado y política hidráulica en México: el conflicto de los indígenas mazahuas, Agua Y Territorio, 4, 21 29,2014

Gómez-Valdez, M. I. and Palerm-Viqueira, J.: Abastecimiento de agua potable por pipas en el valle de texcoco, méxico, Agricultura, Sociedad Y Desarrollo, 12, 567-586, 2015.

Greene, J.: Peri-urban bottled water consumption in western Mexico, Unpublished raw data, 2017.

Hansen, A. M. and Juárez-Corzo, C.: Evaluation of the Pollution of Hydrological River Basins: Priorities and Needs, in: Water Resources in Mexico: Scarcity, Degradation, Stress, Conflicts, Management, and Policy, edited by: Spring, U. O., Berlin, Heidelberg: Springer Berlin Heidelberg, 201 pp., 2011.

Hidalgo J. and Pena, H.: Turning water stress into water management success: experiences in the Lerma-Chapala River Basin, in: Integrated Water Resources Management in Practice, edited by: Lenton, R. and Muller, M., Earthscan: London, 107-120, 2009. 
INEGI: Encuesta intercensal 2015, available at: http://www3. inegi.org.mx/sistemas/temas/default.aspx?s=est\&c=17484 (last access: September 2017), 2015.

Kimmelman, M.: Mexico City, Parched and Sinking, Faces a Water Crisis, New York Times, available at: https: //www.nytimes.com/interactive/2017/02/17/world/americas/ mexico-city-sinking.html?action=clickandcontentCollection= Opinionandmodule $=$ Trendingandversion $=$ Fullandregion $=$ Marginaliaandpgtype $=$ articleand_r $=0$, last access: 7 September 2017.

Korenfeld-Federman, D., Arreguín, F. I., and López-Pérez, M.: Constructing a framework for National Drought Policy: The way forward in Mexico, Weather and Climate Extremes, 3, 90-94, https://doi.org/10.1016/j.wace.2014.04.003, 2014.

Lenton, R. and Muller, M.: Integrated water resources management in practice: Better water management for development, Routledge, 2009.

Lezama, C.: Construcción social de ciudades no sustentables: el caso de El Salto, Jalisco, in: The Politics of Deterioration: The Urban-Industrial Dynamics of the Santiago River, Jalisco, Mexico, edited by: McCulligh, C., Santana, L., and Lezama, C., Newcastle: WATERLAT-GOBACIT NETWORK WORKING PAPERS, 17-36, 2016.

Madani, K.: Water management in Iran: what is causing the looming crisis?, Journal of Environmental Studies and Sciences, 4, 315328, https://doi.org/10.1007/s13412-014-0182-z, 2014.

Martínez-Austria, P. F. and Patiño-Gómez, C.: Efectos del cambio climático en la disponibilidad de agua en México, Tecnologia Y Ciencias Del Agua, 1, 5-20, 2012.

McCulligh, C.: Alcantarilla del progreso: industria y Estado en la contaminación del río Santiago en Jalisco, CIESAS, 2017.

Mollard, E., Vargas, S., and Wester, P.: Social Participation in Mexican River Basin Organizations: The Resilience of Coalitions, edited by: Berry, K. A. and Mollard, E., Social Participation in Water Governance and Management, 115-135, Earthscan, 2010.

Ortega-Gaucin, D., López-Pérez, M., and Arreguín-Cortés, F. I.: Drought risk management in Mexico: progress and challenges, in: 10th International Conference on Risk Analysis, 6, 161-170, https://doi.org/10.2495/SAFE-V6-N2-161-170, 2016.

Pacheco-Vega, R.: Agua embotellada en México: de la privatización del suministro a la mercantilización de los recursos hídricos, Espiral, 63, 221-263, 2015.
Peña-Ramirez, J.: Crisis del agua en Monterrey, Guadalajara, San Luis Potosí, León y la Ciudad de México, Mexico, D.F., Universidad Nacional Autónoma de México, 2012.

Quintero, S. G.: El uso político del agua, Algunos ejemplos y reflexiones, edited by: Ramirez, J. P., El agua, espejo de los pueblos Mexico, D.F.: Plaza y Valdés, 265-281, 2004.

Ramón-Lahera, V.: Infraestructura sustentable: Las plantas de tratamiento de aguas residuales, Quivera, 12, 58-69, 2010.

Richter, B.: Chasing Water, Island Press, https://doi.org/10.5822/978-1-61091-537-3, 2014.

Schouten, M. and Schwartz, K.: Water as a Political Good: Implications for Investments, International Environmental Agreements, 6, 407-421, https://doi.org/10.1007/s10784-006-9013-3, 2006.

Scott, C. A. and Banister, J. M.: The Dilemma of Water Management "Regionalization" in Mexico under Centralized Resource Allocation, International Journal of Water Resources Development, 24, 61-74, 2008.

SEMARNAT: Agua producida, facturada y no contabilizada en ciudades seleccionadas con más de 500 mil habitantes, available at: http://apps1.semarnat.gob.mx/dgeia/compendio_2013/ archivos/01_agua/D3_AGUA07_07.pdf (last access: 7 September 2017), 2013.

Stoltenborg, D. and Boelens, R.: Disputes over land and water rights in gold mining: the case of Cerro de San Pedro, Mexico, Water Int., https://doi.org/10.1080/02508060.2016.1143202, in press, 2016.

Torregrosa-Armentia, M. L. and Jimenez-Cisneros, B.: Challenges Facing the Universal Access of Water and Sanitation in Mexico, edited by: Castro, J. E. and Heller, L., Water and Sanitation Services, Earthscan, 338-347, 2009.

von Bertrab, É. and Wester, P.: Gobernabilidad del agua en México, La crisis de agua de Guadalajara y el destino del Lago de Chapala, Medio Ambiente Y Urbanización, 62, 143-160, 2005.

Watts, J.: Mexico City's water crisis - from source to sewer, The Guardian, available at: https://www.theguardian.com/ cities/2015/nov/12/mexico-city-water-crisis-source-sewer (last access: 7 September 2017), 2015.

Wester, P., Hoogesteger, J., and Vincent, L.: Local IWRM organizations for groundwater regulation: The experiences of the Aquifer Management Councils (COTAS) in Guanajuato, Mexico, Natural Resources Forum, 33, 29-38, 2009.

World Economic Forum: Water Security: The Water-Food-EnergyClimate Nexus, Island Press, Washington, D.C., 2011. 